\title{
Notes on the Architectonics of the Public Will: From the Pedimented Primitive Hut to the French Pantheon of Quatremère De Quincy
}

\author{
Yasir M. Sakr, Naif A. Haddad* \\ Faculty of Architecture and Design, American University of Madaba (AUM), Madaba, Jordan
}

Received April 25, 2021; Revised July 5, 2021; Accepted July 19, 2021

\begin{abstract}
Cite This Paper in the following Citation Styles
(a): [1] Yasir M. Sakr, Naif A. Haddad, "Notes on the Architectonics of the Public Will: From the Pedimented Primitive Hut to the French Pantheon of Quatremère De Quincy," Civil Engineering and Architecture, Vol. 9, No. 5, pp. 1590-1602, 2021. DOI: 10.13189/cea.2021.090529.
\end{abstract}

(b): Yasir M. Sakr, Naif A. Haddad (2021). Notes on the Architectonics of the Public Will: From the Pedimented Primitive Hut to the French Pantheon of Quatremère De Quincy. Civil Engineering and Architecture, 9(5), 1590-1602. DOI: 10.13189/cea.2021.090529.

Copyright $@ 2021$ by authors, all rights reserved. Authors agree that this article remains permanently open access under the terms of the Creative Commons Attribution License 4.0 International License

\begin{abstract}
This paper highlights the crucial endeavour of the French neoclassical theoretician Quatremère De Quincy (1755-1849) to appropriate the theory of imitation (Mimesis) in architecture peculiar political use towards the end of the 18th century. Quatremère De Quincy, who became the Secretary Perpetual of the Academy of Arts (Académie des Beaux-Arts), was perhaps the most influential and prolific neoclassical architectural thinker of the 19th century. Since his election as a representative of the Commune of Paris to the Legislative Assembly of France at the eve of the French Revolution, Quatremère was active in politics between 1797-1800. The paper argues that Quatremère, preoccupied with the French Revolution's political ideals, upended the notion of architectural representation and its Vitruvian ideal, "the pedimented primitive hut", as was reproduced by Abbe Laugier. The study will show that, driven by a secular political vision, Quatremère equated architecture with the "Public will" (la Volonté Publique). Thus, not only Quatremère redefined architecture in linguistic or socio-political terms, as current scholarship generally contends, more importantly, he also redefined politics and its emerging nation-state, society, and public, all in architectural terms. He dismantled the idealist classical canon of referential "imitation" and replaced it with a "projective abstraction" that became the foundation of a modernist architecture concept. The study correlates the basic constructs of Quatremère's architectural theory (i.e.,
\end{abstract}

allegory, architecture, and character), which he articulated in the (Encyclopédie méthodique de l'architecture) during his active political career in the early years of the French Revolution between 1789-1794 with contemporaneous documents of his actual design practice when he was the architect in charge of shaping the French Pantheon as the premier national monument of the Revolution.

Keywords Quatremère De Quincy, Architectural Theory, Neo-classical, Hellenistic Architecture, French Revolution, Modern Nation-State, Pantheon, Type, Character, Allegory, Surface Design, Research through Design

\section{Significance and Contribution of the Study}

The study critically examines and develops ideas implied in recent studies of Quatremère De Quincy. These studies, which proliferated over the last decades helped revise long-held assumptions about his theoretical contribution and established its formative role in modern architecture. Earlier, many scholars generally cast Quatremère as a mere reactionary follower of Abbe Laugier. He supposedly produced an unchanging body of thought aestheticizing architectural representation as an 
"abstract". He universalized "imitation" of the Classical precedents of Greek antiquity, which epitomized the "pedimented primitive hut" (La Cabane) $[1,2,3]$.

In contrast, architectural historians like Neil Levine, Samir Younes, and specifically Sylvia Lavin underscored Quatremère's pioneering contribution in remodelling architecture as a language that operated in terms of "signification" as opposed to "imitation". Thus, instead of being conceived as a natural ideal, "the pedimented primitive hut" became a conventional referential meaning $[4,5,6]$.

However, these architectural historians did not sufficiently account for the worldliness of Quatremère's architectural theory of representation and the extent of its interplay with the socio-political context of his life, elements which, if carefully examined, could challenge their linguistic reduction of his theory. Nor did these recent architectural studies pay enough attention to the reciprocity between Quatremère's theory and his actual design practice - because he was essentially cast as a mere theoretician and academician with no actual architectural design practice.

On the other hand, Art historians paid more attention to the political aspects of Quatremère's career and theory, especially during the French Revolution [7]. They noted his recognition of the public role of art in his campaign to open private art saloons to the public and his central role in remodelling the French Pantheon. These historians, however, limited his contribution to appropriating art forms, especially sculpture, as instruments of allegory in disseminating the ideological agenda of the Revolution. This exclusive focus of recent scholars on Quatremère's art theory and allegory precluded a deeper understanding of the interplay between his political career and his architectural theory, an understanding which would have revealed the more critical nature of his legacy. A noteworthy exception is Melanie Pocock's dissertation on Quatremère's role in remodelling the Pantheon, which drew upon its original archival documents [8].

This paper will show that driven by a secular political vision, Quatremère equated architecture with "Volonte public" (People's general will). Not only he redefined architecture in linguistic or socio-political terms, but he redefined politics and its emerging nation, society, and public, all in architectural terms.

In doing so, Quatremère dismantled the idealist classical canon of referential "imitation" and replaced it with a "projective abstraction" that would become the foundation of a modernist conception of architecture. In addition to discussing connections with visions of Enlightenment thinkers, the study will also point to intriguing cross-cultural and disciplinary parallels between Quatremère's vision and the sociological thoughts of the medieval Arab thinkers' Ibn Khaldun and the "symbolic approach of illusion to the surface design" in the Hellenistic architecture of the Macedonian tombs
[9].

This symbolic approach, the study concludes, contributed "to an effective branding and image-making within the larger context of modern nation-state building which may have a lasting impact on the architectural design even today" [9].

This study correlates the basic constructs of Quatremère's architectural theory-allegory, architecture, and character, which he articulated in the Encyclopedie Methodique d'Architecture during his active political career, at the eve and early years of the French Revolution between 1789-1794 — with the original technical progress reports of his design practice, Extrait du premier rapport présenté au directoire dans le mois de Mai 1791, sur les mesures propres à transformer l'église dite de Sainte-Geneviève en Panthéon Français (Paris, 1792).

It was during the same period, Quatremère was the architect in charge of re-shaping St-Genevieve Church by Jacques-Germain Soufflot, as the French Pantheon, the premier national monument of the Revolution. The other primary sources for this study are Antoine-Chrysostome Quatremère De Quincy, Encyclopedie Methodique d'Architecture, Vol.1-2 (París, 1788) and respectively, all quotes in this article are our translation unless otherwise notified.

\section{Introduction; Desacralizing the "Ideal" of Architecture}

A brief account of the transformation of the "ideal" in architectural theory in the 18th century will help underscore Quatremère's De Quincy crucial contribution to the concept of architectural representation. By examining texts by Blondel, Boullée, and Luagier, among others, Marc Grignon, Juliana Maxim and subsequently Wittman remarked how the development of the modern public sphere in eighteenth-century France led to a significant change in architectural theory focusing on the notion of the "Character" (caractère), which offered an internal criterion by which to conceive architectural projects [10].

A forerunner of Quatremère, Abbe Laugier is widely perceived as representing the rising currents of Rationalism in Western society in the 17 th century $[11,12$, $13,14]$. In place of the long-accepted transcendental humanist notion of the "general", the Abbe substituted an objectified/"natural" model of imitation for architecture. He appears to have reconnected architectural theory to Vitruvius' thesis of the primitive wooden Hut as the origin of architecture.

Laugier's secularisation of metaphor pushed further Claude Perrault's assault on the canon of the human body as an absolute "general" or "Ideal" for imitation by architectural orders [15]. Perrault, one can argue, posited the public as an ideal of architecture when he declared that 
the metaphorical connection between the human body and classical orders is arbitrary and was established only by a social convention [13]. Perrault first declared his position in a footnote in his French translation of Vitruvius's De Architectura [13].

Laugier accordingly declared in his influential Essai sur L'architecture in 1753 that the human body is not the object of imitation and thus cannot be taken as the origin of architecture and its orders [13, 14]. Instead, it was the "primitive wooden hut" (la cabane), the first habitation of man, which is to be taken as such. It represented nothing more than a rational fulfilment of man's material needs and efficient utilization of the available resources, in this case, the timber.

Laugier explained the "Hut" as the universal shelter invented by human society when it had reached a degree of maturity, which released the truly human faculty of reason. Constructed of vertical logs supporting others horizontally jointed to form a pointed/pedimented roof, the Hut embodied the fundamental architectonics and rules of composition that were to become the object of imitation for architecture (see Fig. 1).

In Laugier's view, the primordial Hut was transformed into the permanent stone structure of the antique Temple. Despite this material change the Temple still adhered to the original tectonics of the "Cabane," a frame structure by vertical force supporting horizontal weight in the form of detached columns, straight entablatures and a correctly positioned pediment which prefigure the trabeated profile of classical temples $[15,16]$. This simple "rustic hut", Laugier declares, "is the model from which all glories of architecture begin" [11, 17]. To illustrate his theory, the drawing that fronts the 2nd edition of Laugier's Essai of 1753 featured a woman which personified architecture resting on the ruins of a building of Ionic order while looking at a naked child representing humanity. She points to a primitive frame structure built in a forest tying the trunks of four adjacent trees with their upper branches aligned to form a steep triangular roof. The depicted configuration alludes, too, to the transparent ribbed frames of Gothic churches. Laugier was noted for his appreciation of the Gothic style.

Laugier echoed the increasingly popular notion of the "noble savage", preached by Enlightenment thinkers like Jean Jacque Rousseau in his 1761 well-known Novel $L a$ Nouvelle Heloise (appeared in 1761). Rousseau saw primitive man as embodying primordial good instincts and simple tastes. However, unfortunately, the ideal primitive was corrupted and ultimately, in the mind of Rousseau, deprived of happiness by civilization, particularly by urban life, class distinctions, and governmental tyranny.

Laugier, evidently influenced by the ideal of the "noble savage", envisioned the "pedimented primitive hut" and all that it represented as an embodiment of pure, uncorrupted architectural principles [14]. He saw it as an antidote to the excesses, corruption and bizarre stylization brought by the Baroque and Rococo styles, such as the broken pediments, engaged columns, etc.

One can argue that Laugier's contemporary Jacques-Germain Soufflot physically realized the former's theoretical construct in the design of the Church of St-Geneviève (now Le Panthéon) in Paris, 1755-90 (see Fig. 2). Laugier and Soufflot keenly followed each other's works. St-Geneviève's Church, which will play a significant role in Quatremère's architectural discourse, is considered one of the first neoclassical buildings. In his Essai, Laugier demanded that the church design must embody the following attributions of three elements derived from the primitive Hut: "Based on a "Latin" crossed plan; the columns are perpendicular and detached; the entablatures rest upon the columns in plat-bands, and the pediments are not upon the breadth of the building; they are always placed above the entablature" [11].

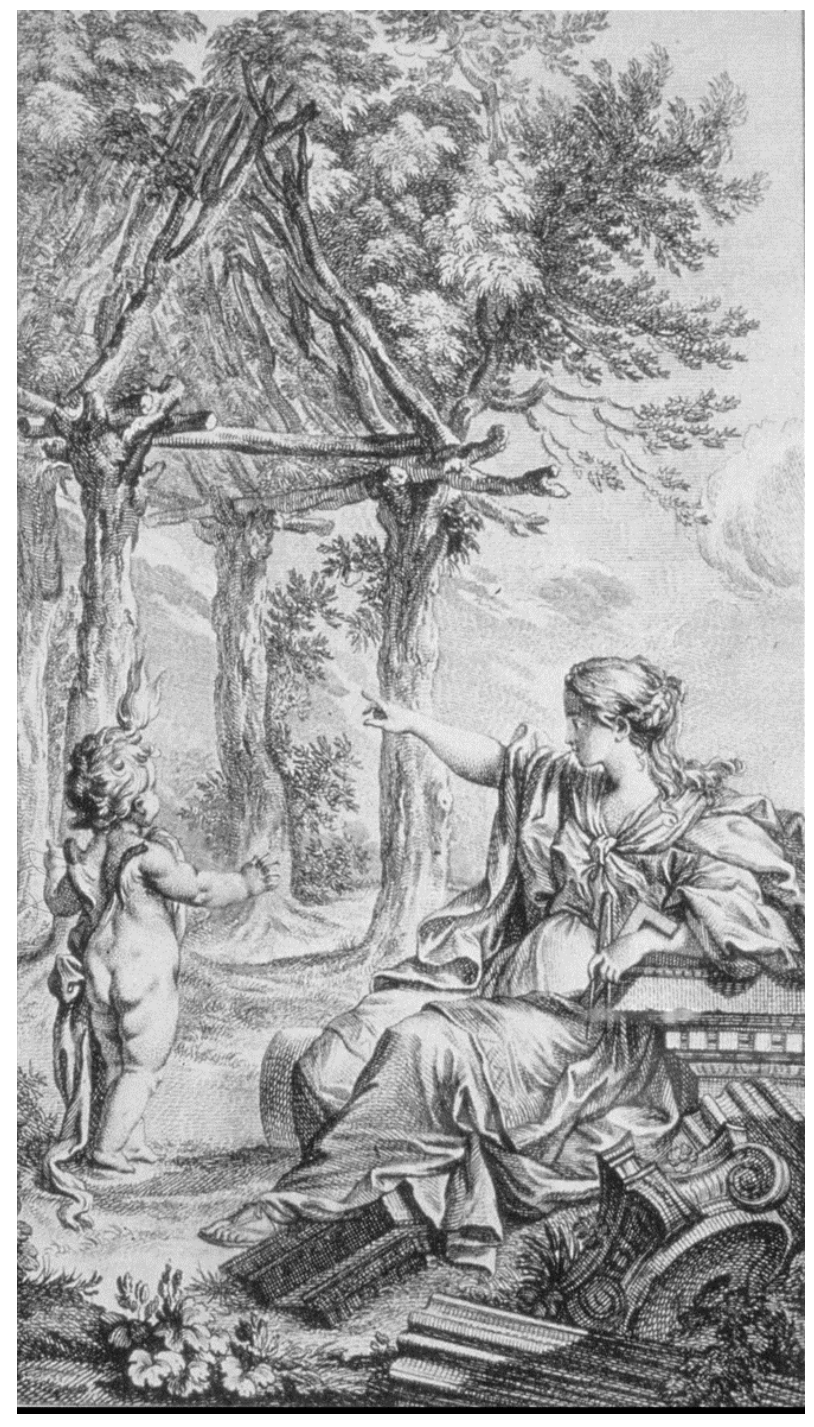

Figure 1. Charles Eisen (1720-1778), engraver, Marc-Antoine Laugier, author, allegorical engraving of the Vitruvian primitive Hut at the frontispiece of Laugier's Essai sur l'Architecture 2nd ed. 1755.

Fronted by a Corinthian styled portico, St-Geneviève 
church is a frame structured by elongated slender columns of Corinthian order currying a light vaulting system. Shaped after a cruciform plan, its detached columns, straight entablatures and a correctly positioned pediment, St- Geneviéve reflect Laugier's three essential elements of the primitive Hut.

Universalized as it was, Laugier's crucial contribution was soon critically taken up by Quatremère both theoretically in his pre-revolutionary writings and practically during the French Revolution in refashioning Scoflot's St. Genevieve as the Pantheon of France.

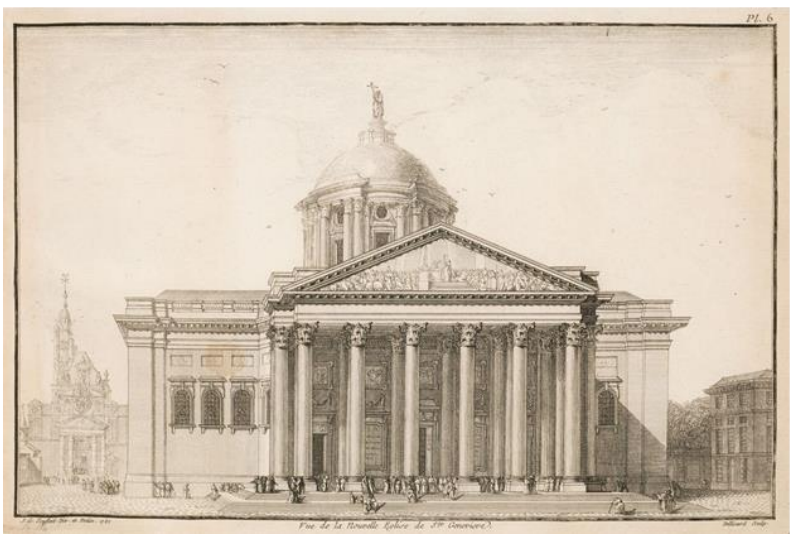

Figure 2. Jérôme Charles Bellicard, engraver. Jacques Germain Soufflot, architect. Perspective view of the projected church of Sainte-Geneviève showing Église Saint-Étienne-du-Mont in the background, 1757. (Collection Centre Canadien d'Architecture, Montréal, reference number: DR1987:0071:006).

https://www.cca.qc.ca/en/articles/issues/9/let-us-assure-you/32749/the-p olitical-life-of-a-building

\section{Quatremère Politicization of Metaphor: Subverting the "Hut"}

In order to understand Quatremere's critical impact on re-conceptualizing metaphor in architecture, it is vital first to clarify his conception of the "Character". Quatremère's essay on "Character," in the 1788 Encyclopedie Methodique, underscores both the metaphorical raison d'etre of architecture and the secular social nature of its "general." [18, 19, 20]. Character, here, is defined as a particular physical representation of an ideational general [18]. Quatremère enumerates the geo-political "general factors" which determine architectural form even in diverse regions, climates, or political systems and lists three types of architectural character, which correspond to a classification of metaphors/imitation. These three characters are arranged according to:

(1) a hierarchy of "general" ends,

(2) ideas in human societies, which are represented in the behavior of their people,

(3) material objects.

Quatremère then defines their three respective metaphors in architecture:
(1) The first is the "Essential Character" which is the primary metaphor in architecture. It represents constant climatic and physical causes, uniformity of general habits (i.e., culture), and collective tendencies and morals [18]. For Quatremère, the essential character of Western civilization leads directly to the "Hut". The "Hut" is a product of geography, the collective spirit, and morals, and, first and foremost, the democratic spirit of ancient Greece [18]. The "Hut" became the formative principle (or "Type" as he later would term it) that subsequently informed the development of Western architecture, even when building material changed from timber to stone. Quatremère lists the "Hut" in contradistinction to the other two types governing the non-western cultures, each expressing a different environmental and socio-political context- the "Tent" for the desert regions and the "Cave" for the Ancient Egyptian civilization [19, 21]. In so doing, Quatremère advances a relativist vision that ends the centrality of the "Hut" as a universal reference for architecture. Contextualizing the "Hut" exemplifies Quatremère's emphasis on the socio-political importance and role of architecture.

(2) The following metaphor for Quatremère is the "Distinctive Character". It is a particularisation of the essential character. The distinctive is the character of originality. It represents accidents or circumstances of the generals, such as governing social and political institutions that distinctive character of architecture to the nation from each other and from within [18]. Thus, Egyptian architecture is characterized by massiveness, Chinese by lightness, Greek, as the "Hut" testifies, by harmony and grace. Quatremère's subsequent practice, we will argue, identifies more with the "Distinctive" than with the third species of metaphor, which is the most technical and "Allegorical" compared to the "Essential" and "Distinctive" metaphors.

(3) The third of Quatremère's metaphors in architecture is the "Relative" character. It is determined by technology, material, and local customs. This is the internal character, localization of the distinctive character. It represents the function, purpose, and usage of the building and its interior [21]. In his Dictionaire Historique, Quatremère articulated more precisely the dual notions of "Type" and "model," which respectively correspond to the dual notions of the "essential" and "relative" characters: "The word 'type' represents not so much the image of a thing to be copied or perfectly imitated as the idea of an element that must itself serve as a rule of the model... The model, understood in terms of the practical execution of art, is an object that must be repeated such as it is; Type, on the contrary, is an object according to which one can conceive works that do not resemble one another at all. Everything is precise and given in the model; everything is vague in the Type..."

Quatremère's "relative character" might be considered 
analogues to the way Hellenistic architects conceptualized architectural façade design, in association "development of barrel-vaulted roof construction technology of the Macedonian tombs " $[9,22]$, which had a significant role for the following periods. It also draws attention to the way Gottfried Simper's theory of cladding and its vision of dematerialization was "associated with the development of construction techniques associated with the industrial and revolution" [23].

To summarize, Quatremère's first character is "synonymous with strength and grandeur. The second is synonymous with physiognomy or originality. The third is propriety or convenience" [18]. Further scrutiny of Quatremère treatment of character underscores his focus on the socio-political effects of the representation of architecture. Even though, at first look, it might appear that nature, including climate, is the predominant "General" of architectural metaphor, for Quatremère politics outweighs nature. In conclusion, Quatremère believed that "political causes of long duration have a lasting effect on the moral character of people, comparable to that of nature" [18], and that, in representing a collective political ideal, architecture achieves "the uniformity of the general habits and morals of a nation" [18].

\section{Quatremère's Architectonic Conception of the Public Will "Volonté Publique"}

This section examines Quatremère's identification of the "Public Will" as the ideal of architectural representation and its impact on his approach to "allegory." Quatremère's thoughts testify to the profound impact of the social and political upheavals in the last two decades of 18th century France on architectural theory [24]. His ideological concerns were, in turn, reflected in his changing treatment of metaphor/imitation, with which he was almost excessively preoccupied.

The omnipresence of metaphor in Quatremère's different subjects in the "Encyclopedie methodique" is indeed remarkable. Key subjects such as "Character," "Imitation," "Allegory," "Hut", and of course, "Architecture" is all commonly founded on the idea of metaphor as "the substitution of the idea, moral impression, feeling in bodily form". The first two volumes of Encyclopédie méthodique, which included the influential entries on these topics - "Allegory", "Character", "Architecture"—were respectively published in 1788 and 1801. During that formative period of the French Revolution, Quatremère was most involved in politics [7, 19, 25].

Quatremère was elected as a Commune de Paris representative in 1789-90 and as a member of the
Assembly Legislative, which replaced the National Convention in 1791 [25, 26]. Drafting a new Constitution, deputies of the Assembly Legislative decreed revolutionary reforms to help create a new society and (public body) of dependent individuals with equal rights. The new constitution drew on "the Declaration of the Rights of Man." Replacing the absolutist monarchy and canonical authority of Church, the new "Constitution" comprises secular abstract "Generals" which define a new Public body; the core of which is the "General/Public Will" of individuals which binds them equally in a "social contract" to the "nation".

What Quatremère had accomplished was to secularise further the essence of metaphor in architecture, namely, the idea of the "Cabane," appropriating and equating the primitive Hut into the socio-political Generals of the new French constitution. Thus, Quatremère identifies with a new type of government dethroning the authority of religion and the absolute monarchy and replace it with the will of the people:

"Government is a political organization from which results in an immediate action of the public will (Volonte Publique) upon a particular..."[18].

Quatremère's sociological conception of government and society as the expression of "the public will" is identical to Rousseau's revolutionary notion of the "general" will [1,27]. Both Rousseau's "general will" and Quatremère's "Volonte Publique" are distant from nature and, thus, from the notion of the "noble savage." The two concepts are, in essence, abstract and artificial. Both Rousseau and Quatremère replaced the 'natural and divine generals/ideals' with a socio-political secular ideology, that is, "civil religion." Thus, Rousseau declares:

"The moment men leave the state of nature and set up a society, that act of association brings into being a collective moral body in the place of the particular persons of each contracting party ... which from this same act receives its unity, its common personality (Moi commun), its life and its will..." [28, 29].

The substitution of the collective social will (Volonté Publique) for "nature" is seen throughout Quatremère's late 18th century writings, and it directly affected his conception of architectural metaphor. This is shown in the above-cited statement that he correlates the "Volonte Publique" artificiality with the "fictitious reality" of the Hut. In conformity with this correlation, Quatremère repeatedly declares that architecture has "no model in nature to imitate". This again affirms the diminishing significance, for him, of nature as an object of metaphor in architecture. It is for the architect both to determine and produce the ideal object and the imitation:

"[The architect's] imagination must at once create both the model and its imitation..." [30, 31].

The architect's imagination is, however, not individualistic but collective. It must be so morally, for 
the invention of "ideals" and "generals" by the few ruling elites furthers their unchecked arbitrary exploitation of the people. Quatremère declares:

"The architect then is not free to arrange arbitrarily in the edifices he builds and to use their indistinctly all the resources of his art. Public opinion surrounds him; it prescribes for him the tone, the style he must take. ... So then, before undertaking any construction, the architect will consult the relation between the people's ideas and the monument with which he is entrusted" [30]. Furthermore, in another statement: "This correspondence of sentiments between people and artists is indispensable to all genres, But an architecture that lacks a positive model around which both the principle of imitation and the judgements of the spectator can need it more than any other art" [30].

At this stage, Quatremère blurred the distinction between the ideational General of the 'Essential' Character associated with 'Type' and that of the 'Relative' character of the corporeal 'Model'. In effect, he sublimated the latter to the abstract reality of the former and vice versa, indicating the liminal 'distinctive' character associated with originality. In his entry on "Architecture" in the Encyclopedie Methodique, Quatremère explains:

"[The Hut] is only a fictitious given a sign of convention and a rallying point of agreement...We might even go as far as conceding that it is only a fable, an allegory invented in order to contain meaning and a commonplace doctrine" [24] (modified by the authors).

Since the model of the "Hut" is unreal, there is nothing to imitate except a general social ideal, a "public will" which lacks specificity or corporeality and which is itself metaphorical, artificial, and fictitious [32]. Winkelmann's earlier acute idealization of the Greek antique made it easier for Quatremère to affiliate the "artificial" "general will" with the fictitious "primitive hut." Finally, this artificiality of public will (Volonté Publique), according to the secularist Quatremère, rendered the traditional conception of metaphor as allegory obsolete - for allegory, must be, of course, a sensory representation of particular and definite ideas or objects. The employment of 'Allegory,' associated with the relative corporeal character, makes architecture susceptible to ideological manipulation.

Quatremère's secularist worldview is underscored throughout his essay on "Allegorie," in the Encyclopedie Methodique, by a fierce attack on those "foreign doctrines [which] result from little knowledge and false ideas about allegory." The theoreticians to whom he refers, whether the clergy or the then-burgeoning Freemasons, had embraced a mystical, esoteric notion of metaphor corresponding with the presumed divine origin of architectural language [14]. Quatremère comments:

"According to them, architecture like all arts had its origin in religious cult... No longer do they see in a pediment the representation of a roof... The roof to their eyes is only a mysterious triangle, an emblem of the divinity" [4, 18].

For his part, Quatremère refused to see the 'emblem of the divinity' in any building, dismissing examples of religious architecture as exceptional [18]. In addition to the (mystical) divine conception of the "General" of architecture, Quatremère was combatting (perhaps too polemically) another implication of "allegory" for the concept of metaphor - the sensory and figurative nature of the referential link evident in the animate-inanimate transference of allegory. Such figurative nature contributes to the objectification and ideological manipulation of the "General" as a natural model by opportunist regimes.

Quatremère declared the expulsion of allegory from the realm of architecture at the beginning of his essay [18]. Quatremère critically observed how architecture was subjugated to allegory, and its use as a tool for political propaganda, during the rise of the Rococo style of the "Ancien Régime," and later in his subsequent remodelling of the Pantheon during the French Revolution [33, 34]. Quatremère declared that "allegory is foreign and superfluous to architecture;" the latter has the integrity to be self-referential; "the roof, i.e., the pediment, is simply a roof." According to Quatremère, "allegory which is intrinsic to sculpture, painting, and ornament is an accessory added to architecture only subsequently, due to progress in civilization" [18].

\subsection{Quatremère, Ibn Khaldun and the Sociology of the Monument}

Quatremère's thoughts on allegory echo the sociological conception of architecture by the medieval Arab thinker Ibn Khaldun (1332-1406). The orientalist Silvester de Sacy (1826) began publishing translated excerpts of Ibn Khaldun's Prolegomena and his biography in 1806 in the "Journal des Savants" when Quatremère was one of its significant patrons and contributors [35].

What begs further inquiry of the interplay of the ideas of Quatremère and Ibn Khaldun is that Quatremère's first cousin, Etienne Quatremère, was the first to publish the fully edited Arabic version of Prolégomènes d'Ebn-Khaldoun (1858) [36].

To Ibn Khaldun, the architectural monument is a surrogate to the lost natural group feeling ('Asabiyya) of the tribal community, which stemmed from the blood ties of kinship and/or zealous religious bonds [45, 36]. This organic group feeling was lost after tribes moved from the countryside/desert to the cities of the regimes/dynasties they conquered and displaced.

Once these victorious tribes settled and established new dynasties, their natural group feeling will be replaced by artificial citizenship and master-client relationship. However, the new collectivity is not as strong as the 
previous one, which was based on blood affiliation, mobilized and galvanized society around the state's joint/national goals. Buildings, i.e., monuments, become at this phase essential in reinforcing and legitimating the new artificial social ideals with their distinct architectonic presence. However, as the urbanized society prospers, it increasingly adopts luxurious lifestyles with the excessive refurbishment and ornamentation of buildings/monuments.

This, in Ibn Khaldun's view, will ultimately lead to a state of complacency among ruling elites and society, resulting in their downfall. They will become susceptible to conquest by more "organically" motivated groups. Quatremère was respectively preoccupied with the indispensable role of architectural monuments in consolidating socio-political cohesion while simultaneously pre-empting its "allegorical" deployment as an agent of social decay (as was associated with the Rococo Style). His affiliation of the socio-political General of the "Volonte Publique" with the abstract reference of the primitive Hut led him to censor the "particular" and the "allegorical" in architectural character.

Quatremère believed that the homogenization of the character of buildings and architectural fabric would contribute to social harmony and civil Equality and lessen class distinctions. However, the bizarre, extravagant, individualistic architecture, and the impression of disunity it gives, are to Quatremère synonymous with the excesses and exploitation of the ruling elites, and ultimately the demise of social order [18]. Therefore, to ensure, egalitarianism and the immediacy of public communication, buildings as metaphors had to be stripped from superfluous sensory accretions (i.e., allegories), which for Quatremère are equated with individualism and caprice.

\subsection{The Architectonics of the Ideal as Illusion}

As an object of imitation, the Hut becomes, in Quatremère's thesis, no more than a set of historical abstract architectonics. It is, in short, no longer a hut, no longer "la cabane," but only the illusion of a hut. This is not to say that the illusory Hut does not represent authoritative principles upon which the architect must draw. Quatremère names these principles:

"...that the strong must carry the weak, that solidity must be real and apparent, that the use of all parts must be justified by necessity... that the parts must be subordinated to the whole and that symmetry and regularity be tied to order and solidity. So that simple relations are the most beautiful..." [18].

Though these axioms are natural and even self-evident, the construct to which they refer is entirely artificial. Quatremère concludes his list by finally replacing allegory with illusion: "If these maxims are indisputable, what does [it] matter if the real or imaginary existence of the cabin/ hut is true or false?" [18, 19].

To reiterate, the legitimacy of the principles cited above is no longer based on the sacred or the natural. Both assumptive attributions Quatremère had already discarded. Instead, their legitimacy is derived from the fact that, as social conventions, they are indispensable for collective communication and social order.

To understand how they function as such, one must note the emphasis of Quatremère's above statement on achieving the "unity" of architectural configuration utilizing "simplification," "solidity," and "symmetry." Quatremère was convinced that a hermetic unity and uniformity of design was a pre-requisite for transforming the design totally into a communicative and socially authoritative sign; he thought that the essential "material forms of the intellectual qualities and the moral ideas which can express themselves in buildings... [should be accomplished] by the agreement and the fitness of all the constitutive parts of the building..." [18].

According to Quatremère's cannon, the autonomy of each of a building's internal components shown in complex or asymmetrical configurations should be forsaken in favour of a hierarchical, elemental, and symmetrical organization to accentuate its direct communicative character. This is evident in the very concept of the Hut, a spare embodiment of the principles of unity and simplicity. The new canon is achieved by stripping building types of the superfluous, accidental, and specific (even the distinct), reducing them to extremely simple, uniform, and basic configurations. Thus the "abstract" form of the Doric, for instance, is declared by Quatremère to be the most original order for architecture.

$\mathrm{He}$ extends his new canon to religious architecture, as seen in the Encyclopedia entry for "Eglise" (Church). Quatremère reduces the configuration of the Church to the elemental: a simple single vessel containing a nave and aisles, with a flat roof but without domes or belfries [37].

Quatremère also prescribes this minimal configuration for several other types of public buildings. Accordingly, he denounces the synthetic church designs, adding other elements beyond this basic form [37]. These theoretical prescriptions remarkably prefigured Quatremère's actual design interventions in the following year, when he became the commissioner in charge of shaping the first and most important monument of the French Revolution: The Pantheon.

\section{The Pedimented "Volonte Publique:" Quatremère's Design of the Pantheon}

The National Assembly of France commissioned Quatremère in 1791 to transform Soufflot's incomplete 
Church of St-Genevieve into a secular Temple commemorating great French Citizens [38]. The French Pantheon in Paris, as the building was renamed, would enshrine the remains of important figures of the Enlightenment, such as Voltaire and Jean Jacque Rousseau. Quatremère was appointed as the official architect of the new Pantheon. Pocock's tedious research of original documents of construction reports from that period consolidated the consensus among historians about the decisive role of Quatremère in the Pantheon's 1791 conversion commission and how he wielded quasi-absolute power over its initiation, ideology, design, production, and choice of its allegorical subjects [8].

In the first reports to his client, the new revolutionary authority, Quatremère drew its attention to the significance of the new Pantheon not only a mausoleum but a monument of the nation:

"The National Assembly's decree and its total implications, impose on the Directory the obligation to dedicate the building only and exclusively to the great men and the worship of the homeland"[38].

The French Pantheon was originally a Gothic abbey dedicated to St.Genevieve, the patron saint of Paris before King Louis XV, commissioned Jacques-Germain Soufflot to replace it with a new design in 1755 . The decision of the new revolutionary regime to shape its national monument by transforming St. Genevieve's Church, rather than constructing a new edifice-partly based on Quatremère's recommendation -perfectly monumentalized a critical political program of the Revolution: the de-Christianization of France [38, 39].

During the Revolution, the Church's property was nationalized; its clergy was stripped of their privileges, persecuted, and often murdered. St. Genevieve's relics were put on a public trial, condemned, and burned [40]. In this spirit, Quatremère removed from the Pantheon all allegorical symbols associated with religion-tower belfries, Gothic iconographic windows, the religious statues, and inscriptions in the pediment. The new base relief of the central pediment by Jean-Guillaume Moitte, Quatremère's appointed sculptor, replaced the Radiant Cross by Guillaume II Coustou with its secular themes (Fig.3). Internally, the closure of the windows, coupled with removing religious statues from the ground floor, which restricted the light sources to the Lantern of the Cupola, helped produce a tremendous sombre space in the place of its former bright Gothic interior.

Simultaneously, the ancillary peripheral structures that connected St-Genevieve with the surrounding urban fabric were removed to enhance the grandeur and monumentality of the new Pantheon. However, these reductionist alterations originate from Qautremere's earlier theoretical prescription of the minimalist architectonics of the public monument. The extent of Quatremère's interventions far superseded his original ideological mandate, which was limited to refurbishing the interior and exterior of the Pantheon with new sculptures and iconography.

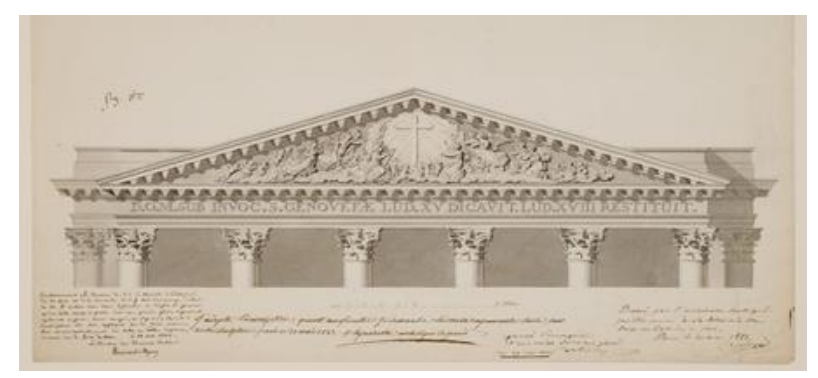

Figure 3. Louis-Pierre Baltard. Detail of drawing showing elevation of the new pediment, Church of Sainte-Geneviève, 1823. (Canadian Centre for Architecture, Montréal, reference: DR1984:1588). https://www.cca.qc.ca/en/articles/issues/9/let-us-assure-you/32749/the-p olitical-life-of-a-building

Quatremère's interventions radically changed the relative architectural character of Soufflot's design based on a symmetrical Greek cross plan fronted by a separate columned entrance. Laugier's Pantheon is, we argue, a model of the primitive Hut which combined "the purity of Greek architecture with the lightness of Gothic (skeletal) construction." Quatremère's most dramatic design decision was blocking the fenestrations of the main facades of the facades of Laugier's design [38] (Fig.4). The subversive effect of Quatremère's intervention did not go unnoticed by contemporary critics. For instance, Legrand [41] commented: "the pretention of correcting his [Soufflot's] model, far from perfecting this model of antiquity, has only disrupted its harmonious proportions."

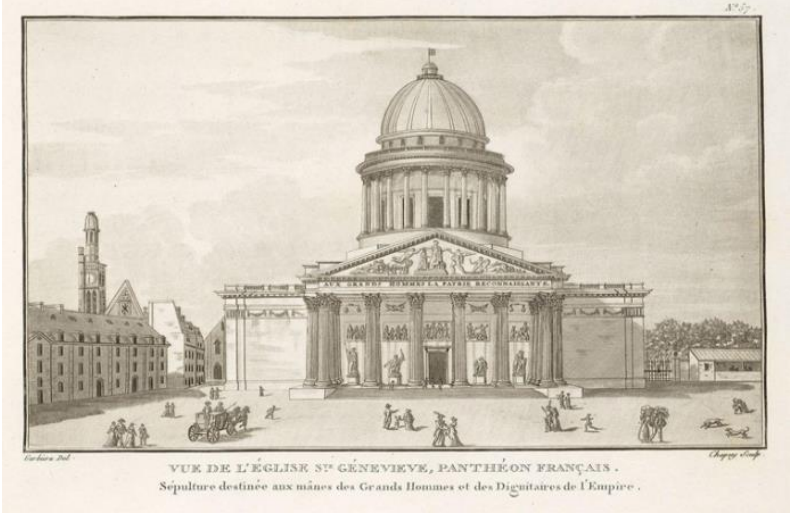

Figure 4. Jean-Baptiste Chapuy after Angelo Garbizza, Vue de l'église Ste Geneviève, Panthéon Français, c.1810, aquatint. (Getty Collection, Los Angeles. (C) Digital image courtesy of the Getty's Open Content Program).

The closure of the windows externally emphasized the materiality of the uninterrupted, unadorned surfaces of the walls of the Pantheon, which balances the permeability of its colonnaded portico, all within a centralized composition of contrasting textures. Quatremère perceived these windows as weakening the distinction between the colonnaded entrance and the main body of the building. 
He must have perceived these windows as undesirable elements denoting the skeletal and ripped Gothic structural system dormant within the walls of the building. By blocking them, Quatremère transformed the central mass of St-Geneviève into an opaque backdrop of the pedimented colonnaded entrance, which emphasized the latter as a detached symbolic element. Coupled with removing religious statues from the ground floor, the closure of the windows restricted the light sources internally to the Lantern of the Cupola, producing a sombre space in the place of the previous luminous Gothic interior. The removal of the windows established the Pantheon's essential abstract formal character as a monument—and its "Philosophique," to use Quatremère's words:

"Another abolition which will add to the character of the building and architecture is the blocking of the windows which used to pierce the walls. Large smooth [surfaces] are pleasing to the eye. Moreover, the interior will gain a lot by removing the daylight at the bottom, which clashed with that from the rim of the big vault. Because of receiving less light, the interior will take on a more serious character; daylight drawn from above will shed on the monument and on architecture itself a more favourable light, more suitable to the spiritual silence of the place" [38].

We can, therefore, argue that Quatremère's alterations produced an abstract, opaque form that is self-referential and does not signify or serve a particular mundane function. The Pantheon was later repeatedly judged dysfunctional even for a mausoleum as it instigated at the time calls to move the remains of the famous figures it shelters to more celebratory outdoor display [42]. Quatremère's intention was evident as to the sui-generic "distinctive" character/nature of his design intervention, which "must always adhere to the rule of avoiding aspects of resemblance between our monument and holy places or cemeteries." [38]. Quatremère's statement can be taken as a rejection of the contemporaneous rival visions, whether the expressive symbolism of the "revolutionary architects" such as Étienne-Louis Boullée or the functionalism of Jean-Nicolas-Louis Durand. The monumental funerary designs by Boullée and Claude-Nicolas Ledoux were shaped after platonic forms abstracting precedents from antiquity. Boullée's design of Sir Isaac Newton's cenotaph can be perceived as an exteriorization of the interior spherical space of the original Roman Pantheon in Rome after he eliminated the pedimented colonnaded entrance that fronted it.

On the other hand, Durand presented an alternative design for St. Genevieve Cathedral akin in crucial aspects to Boullée spherical design. Durand criticized Laugier's design for its excessive number of columns which made the construction cost unnecessarily too expensive. He proposed an economic structural alternative that, in contrast to Laugier's Cruciform, was shaped after a gigantic centrally domed building resting on a circle of columns which in number were only one-third of the former.

Quatremère used ironically self-serving "economic" argument to further suppress allegorical distractions and references to "domed" precedents to accentuate the abstract minimalist form of the pedimented monument. He proposed, on the grounds of cutting costs, to change the material of the colossal statue of 'la renommée' previously designed on top of the cupola, which represented French patriotism, from plaited Bronze to stone. Quatremère's hesitance to erect the statue as documented in his progress reports revealed his hidden agenda. In these reports, Quatremère repeatedly gave conflicting instructions to the sculptors to construct many time consuming and costly mock-ups of the dome to stall the construction of this "allegory."

\section{1 "Public Will;" the Pediment of the Pantheon}

Quatremère hoped his edifice would transcend political ideologies/regimes, or even utilitarian functions, to become a principle that projects its own intrinsic politics to shape society "...The Pantheon would continue to inspire with universal ideals future French generations regardless of their political persuasion [38]".

The monument would be the authentic "Volonte Publique." Indeed, Quatremère insisted that the public be allowed to access and visit the Pantheon while the scaffoldings were still up during its construction so that they would feel, like mortar and stones, as essential elements of the building process [38]. His intentions could not have been timelier and more relevant at a time when the revolutionary regime purporting to represent the "Volonte Publique" had abused it during the reign of terror which placed Quatremère himself under house arrest after three years of his design mandate.

The Pantheon's pediment façade is dissolved to symbolize the revelation of the new era; this new mask surface responds to the power of the newly emerging revolutionary regime. The Pantheon's central pediment, which was "the biggest ever in France," sums up the essence of Quatremère's interventions. Its base relief, which Quatremère conceived with the sculptor Moitte, featured the Pantheon's most obvious allegorical element; one of the few he allowed (Fig.5).

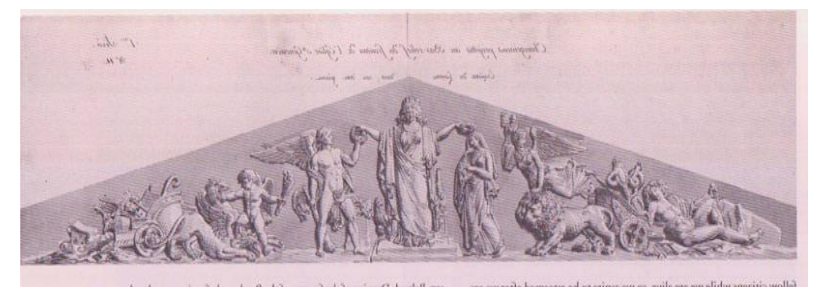

Figure 5. Jean-Guillaume Moitte, drawing of the bas-relief of the central pediment of the Pantheon, Paris, 1790-1792 (Musee Carnavelet, Paris) 
Quatremère sanctioned Moute's pediment, we argue, because it presents an allegory of his theory and design process, an allegory of "counter allegory." In other words, the frontispiece of Quatremère's own "Essai de l'Architecture." Following Quatremère's instructions and revisions, Moitte employed the geometric properties of the triangular form of the pediment to determine the design of the sculptural motifs of its bas-reliefs.

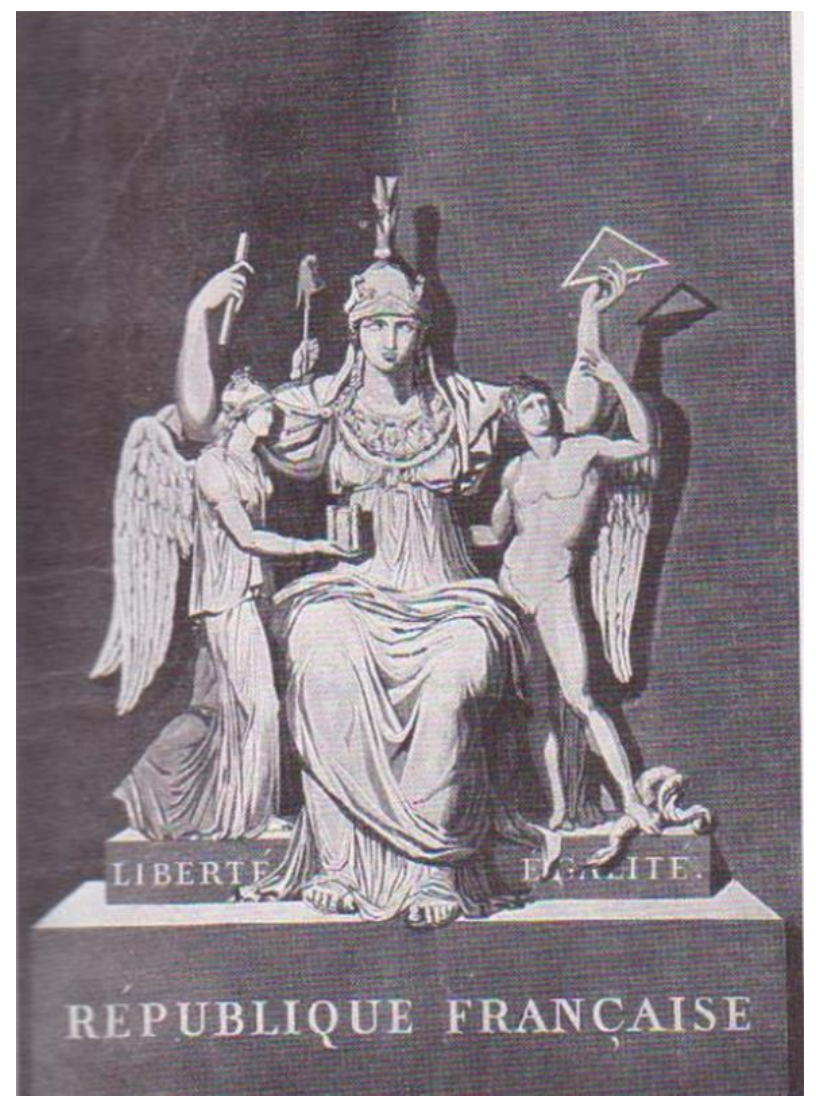

Figure 6. Antoine Quatremère De Quincy, 'La patrie,' an alter proposed for the Pantheon, Paris, 1790-93 (Bibliotheque Nationale, Paris)

The theme of the bas-reliefs of the triangular pediment seems to have been drawn from Quatremère's drawing for the altar's design, which he dedicated to the Motherland under the central dome of the Pantheon (Fig.6).

Quatremère's drawing depicted architecture as a triangle passed by a female figure representing the Motherland (le Patrie) to a winged young man standing beside her on the left flank representing Equality. On the right flank of Motherland stood another figure of a winged woman representing liberty.

The Pantheon's triangular pediment embodies architecture itself, which is simply a roof. Every theme/element it contained is a representation of the triangle's formal and structural attributes. At the centre, the pediment crowns a female figure representing Homeland [43]. She rises from the ground base with her stretched hands, opening the obtuse angle of the triangular pediment to bestow crowns to the winged male figure of
Virtue to her left and to the female figure of Genius, which stands for engineering, to her right. Contrasting the central female figure, Motte squeezed a figure of a fallen man within the acute angle of the lower-left corner of the pediment. Quatremère description of this triangular composition merits citing at length:

"Cleared off the insipid/tasteless rows of clouds, angels and beams which only offend reason, the front surface [pediment], would receive the image of the Homeland as a woman dressed in a long dress accompanied with the symbols which characterize France. With both vast arms extended, she holds in each a crown. To her left, the Genius [i.e., Engineering], shaped like a winged young man, receives the crown, whereas on the other side, the Virtue, under the more modest emblem of a girl, seems to wait for the other crown. Dwelling within the narrowing corner of the pediment are attributes of the vices (defects) and base passions" [38].

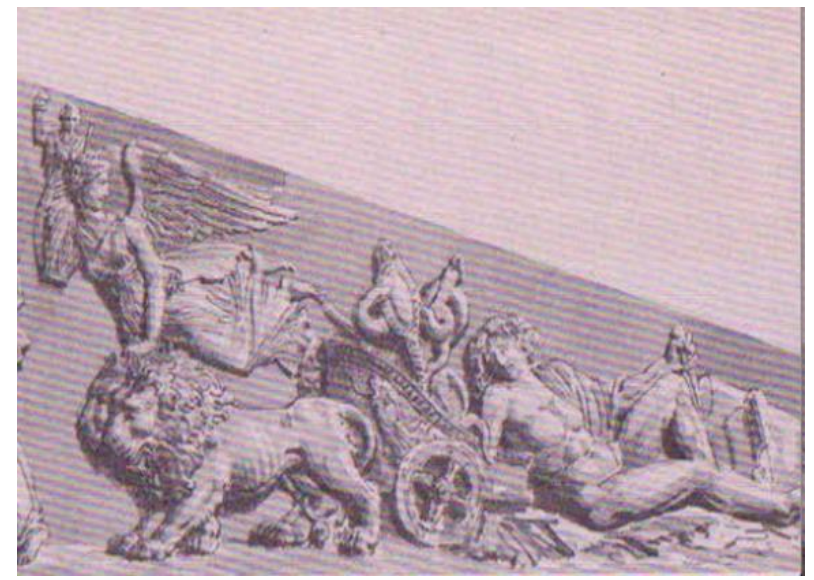

Figure 7. Jean-Guillaume Moitte, Detail of a drawing of the base relief of the central pediment of the Pantheon, Paris, 790-1792 (Musee Carnavelet, Paris).

Stretched over certain ruins, the 'Humiliated" figure, which purportedly represents despotism, holds in his hand a dagger that also looks like a chisel (Fig.7). This male figure intentionally opposes the female motif that fronted Abbe Laugier's "Essay on Architecture" (Essai sur l'Architecture), which personified architecture. There, she was stretching her body over analogous ruins of a Rococo style building. She turned her head away, gesturing to an infant representing humanity, with her hand raised towards the horizon where the 'pedimented' Primitive Hut looms both as a destination and origin.

The humiliated male figure in the Pantheon's pediment is arguably the invisible object of the female's gaze in Laugier's essay. It is an allegory personifying the ill-fated Primitive Hut and its association with the despotism of religion and even the secular ideology of the Revolution itself [44]. It appears as if the architectonics of the architectural monument through the weight of the Pantheon's colossal triangular roof is crushing allegory within it. From 30 metres above, Architecture is looking triumphantly down upon all its viewers. Meanwhile, the 
viewers are looking up at her with awe from the base. It is this gaze that re-inscribes her subjects as public, nation, and Man as Quatremère intended:

"The bas-reliefs placed above these inscriptions will repeat maxims in their imagery. Thus, one would see on the one hand what the Homeland made for man, and the other, what man owes to the Homeland" [38].

All in all, the Pantheon's pediment is evidence of Quatremere's intent to shift attention from the mere construction of images to producing powerful visual effects, where the façade scene might be described as a tour de force of projective abstraction. The façade becomes a dual mask perceived as both a means and an end of expression [9]. We can point here to the analogous phenomenon of the Hellenistic pedimented doorways in Greco-Macedonian architectonics, and the later baroque like segmented pediments that appeared in Alexandria in the second century BCE $[22,48,49,50]$.

\section{Summary and Conclusions}

The paper provided fresh insights into the interplay between architectural theory, history and National politics to encourage architectural historians to develop a new critical vocabulary for two towering neoclassical monuments; the theory of Quatremère De Quincy and the French Pantheon. In particular, the study highlighted Quatremère's subversive endeavour to appropriate the theory of imitation (Mimesis) in architecture for political use towards the end of the 18th century.

It showed how Quatremère, preoccupied with the ideals and politics of the French Revolution and emergent critical sociological thoughts of the Enlightenment, including possibly those of the Arab medieval thinker Ibn Khaldun, in effect advanced a subversive vision that upended the notion of architectural representation and its ideal, the Vitruvian "pedimented primitive hut," which was re-introduced by Abbe Laugier. Quatremère fundamentally transformed the reality of representation in Architecture and its conception. He effectively censored the references of the design of the French Pantheon not only to its Gothic premises but to Laugier's skeletal "Pedimented Primitive Hut" and the allegory behind Soufflot's original design in favour of an abstract form referring to itself.

Quatremère consciously effaced the "Hut" as an ideal type and meaning of a referential language. His subversion of allegory in his early essays on "character" and the corresponding remodelling of the Pantheon foretold its total censorship in his own subsequent theoretical writings. Di Palma [20] noted that Quatremère virtually omitted discussions of the primitive Hut from his post-revolutionary Dictionary.

Rather than an ideal reference or signified, Quatremère transformed the "Hut" into an imaginary signifier within an open-ended system of signification and effects; a process which, by its continued deferral of expressing a definite ideal or function, creates the illusion of a reference to an absolute meaning which does not exist. Only the materiality of architecture exists.

Architecture, i.e. the Pantheon, must be opaque, abstract, minimalist, uniform and stripped of tangible sensory allegories to any particular functional reality, historical precedent, or transient political ideology and regime. The architectural monument has to be so in order to mask the artificial reality of "civil religion," "nation," and "public;" to respectively operate as a discursive machine of social order and discipline; and to act as a magnet galvanizing and "voluntarily" unifying the gaze and will of individuals into collective citizenship. Thus, preaches Quatremère:

"The Homeland is a new divinity for free people, but it is a cult that knows no sects. Obligated to all the assets that can be applied to legitimate it on earth, this cult does not rival the oracles and rewards that came down from the sky. It does not judge decrees of religion; it does not share its temples. But [this cult] wants an altar, around which it links worshipers of a brotherhood privileging neither birthright nor preference nor distinctive signs" [38].

Quatremère finally replaced allegory with illusion. Architectural design must be hermetically sealed in an orthogonal configuration of elements symmetrically streamlined as a monument which blurrs the distinction between the essential reference, i.e. the (conceptual) Type, and its relative (physical) model. In Quatremère's refashioned Pantheon, roles are reversed; architecture becomes the type and nation its model. Quatremère did not merely define architecture in linguistic or socio-political terms, as current scholarship contends. More importantly, he redefined politics and its emerging nation, society, and public, all in architectural terms.

It is worth noting that the functional and semantic indeterminacy of Quatremère's Pantheon would be attested subsequently by the numerous times it alternated its function over the following decades, from a church to a secular monument and back; each usage corresponding to a change of the political regime and ideology [45, 46]. Quatremère prefigured this outcome as he commented at hindsight on the French Revolution's eventual betrayal of the 'Volonte Publique." He described 'his" Pantheon as "a monument that the Revolution attempted to appropriate for itself, by according to it with a political function that it did not hesitate to discredit" [44, 47].

One may also note, at this juncture, the intriguing parallels between Quatremère "projective abstraction" and the thoughts of key thinkers of the nineteenth century, like Bötticher, Hübsch, Viollet-le-Duc, and in particular the German architect and theorist Gottfried Semper (1803-79) who rejected Vitruvius's theory of the "primitive wooden hut" as the origin of architecture $[9,48]$. Semper attempted to do away with a theory of "imitation" that had prevailed 
since the time of Vitruvius. He declared that the "assertion that the wood structure was the origin of architecture is a materialistic way of thinking to be rejected" [9].

To Semper, the building's material is only one of the factors that determine the art form; architecture begins as a symbol, a kind of a phenomenological surface ornament and not simply a decoration of naked structures; He considered cladding and the textile Art and people's communal spirit behind it as the origin of architecture [9]. A case in point was the employment of illusion by the Hellenistic Greco-Macedonian architects who, according to Haddad [22, 49, 50], pursued abstract symbolic meaning through their play with the simple architectural elements of recognition, especially the pediment. "They were searching for new architectural symbolic effects that were no longer dependent upon the typical pre-existing styles/ orders" [9].

Haddad et al. [9] argue that Hellenistic architects could offer different interpretations of the illusion of surface design since they were "freed from the constructional and classical materialist limitations of design". In doing so, architecture becomes a robust phenomenon, as Semper argues; a formal symbolization of human events and the effect of the social gathering, interaction, memories, and emotions associated with human festivity. In other words, as Quatremère envisioned earlier, architecture achieves "the uniformity of a nation's general habits and morals".

\section{REFERENCES}

[1] Schneider, René, "L'esthétique classique chez Quatremère de Quincy (1805-1823)", Paris: Hachette, 1910.

[2] Middelton, Robin, Watkin, David, "Neoclassical and 19th Century Architecture". 2 Vols (Milan: Electa S.p.A.) 1980, p.217.

[3] Steil, Lucien, "On imitation" Lucien Steil.ed Imitation and Invention, articles by Leon Krier and others (London: A.D. St. Martin's Press: 1988, pp-8-9.

[4] Levine, Neil, "Modern Architecture: Representation \& Reality" Yale University Press, 2009, pp.71-72.

[5] Lavin, Sylvia, "Quatremère de Quincy and the Invention of a Modern Language of Architecture" (MIT Press) 1992.

[6] Younes, Samir, "Quatremère De Quincy's Historical Dictionary of Architecture: The True, The Fictive and the Real", Papadakis Publisher, 2000.

[7] Luke, Y., "The Politics of Participation: Quatremère de Quincy and the Theory and Practice of 'Concours publiques in Revolutionary France 1791-1795", Oxford Art Journal. Vol. 10, No. 1, Art and the French State (Oxford University Press), pp. 15-43, 1987.

[8] Pocock, Melanie, "The French Pantheon, 1791: Redefining the dynamics of power in public art", The Society for the Study of French History, University of Bristol; 2009, http://frenchhistorysociety.co.uk/documents/pocock.pdf

[9] Haddad, N., Sakr, Y., Fakhoury, L., "Investigating Gottfried Semper's Symbolic Approach to the Surface Design in Hellenistic Architecture: The Case of the Macedonian Tombs," Mediterranean Archaeology and Archaeometry, Vol. 19, No 3, (2019), pp. 1-16, 2019.

[10] Grignon, Marc \& Juliana Maxim, "Convenance, Caractère, and the Public Sphere," Journal of Architectural Education, 1995, pp.49:1, 29-37, DOI: 10.1080/10464883.1995.10734 661

[11] Laugier, Marc-Antoine, "Essai sur l'architecture", Chez Duchesne, Paris, 1753.

[12] Herrmann, Wolfgang, "Laugier and Eighteenth-Century French Theory", London. 1962.

[13] Mallgrave, Harry, "Modern Architectural Theory: A Historical Survey 1673-1968" (Cambridge University Press) 2005, pp.9, 19.

[14] Vidler, Antony, "The Idea of Type: The Transformation of the Academic Ideal, 1750-1830," Oppositions, no. 8, (MIT. Press), 1977, pp. 95-97.

[15] Wittman, R., "The Hut and the Altar: Architectural Origins and the Public Sphere in Eighteenth-Century France", Studies in Eighteenth-Century Culture, 36(1), 235-259, 2007.

[16] Levine, Neil, "Architectural Reasoning in the Age of Positivism: The Neo-Grec Idea of Henri Labrouste's Bibliotheque Sainte-Genevieve". PhD. Dissertation (Yale University,) 1975, pp.561-577.

[17] Winckelmann, Johann Joachim, "History of the Art of Antiquity. Introduction by Alex Potts." Translation by Harry Francis Mallgrave. Los Angeles: Getty Publications, 2006, 1764.

[18] Quatremère de Quincy, Antoine-Chrysostome "Encyclopedie Methodique d'Architecture", Vol.1-2, Panckoucke, París, 1788.

[19] Younés, Samir, "The True, The Fictive and the Real: The historical Dictionary of Architecture of Quatremère de Quincy", Papadakis: 1999, 1999, pp. 33-41.

[20] Di Palma, Vittoria. "Architecture, Environment and Emotion Quatremère De Quincy and the Concept of Character." AA Files, no. 47, pp. 45-56. 2002. www.jstor.org/stable/29544277.

[21] Quatremère de Quincy, Antoine-Chrysostome, "De l'architecture Égyptienne: Considérée Dans Son Origine, Ses Principes et Son Goût, et Comparée Sous Les Mêmes Rapports À l'architecture Grecque". Dissertation, Qui A Remporté, 1785.

[22] Haddad, N., "Aspects of the Particularity and Creativity of the Nabataean Architectural Culture during the Late Hellenistic and Roman period", Proceedings of the First International Conference of the Nabataean Culture, Petra: 5 - 8, May 2012, in Studies on the Nabataean Culture I, Publication of the Deanship of Scientific Research, The University of Jordan- Amman, 2013, pp. 103-117.

[23] Al Hassani, Jumana Mohamed, "From Object to Effect: The Transformation of Cladding Conception in Architecture", Master thesis, University of Jordan, 2004. 
[24] Hinchcliffe, T., "Introduction to Quatremère's translated essays "Idea," "Imitation," "Architecture" and "Character," "Encyclopedie Methodique in 9H, no.7, 1985, pp. 25-26, 34.

[25] Gauchet, Marcel, "The Rights of Man," In Francois Furet and Mona Ozouf ed., A Critical Dictionary of the French Revolution, Cambridge, Mass: Harvard University Press, 1989 , p. 819.

[26] Doyle, William, "The Oxford History of the French Revolution". Oxford: Clarendon Press, 1989.

[27] Di Palma, Vittoria, "Blurs, Blots and Clouds: Architecture and the Dissolution of the Surface", AA Files, No. 54 pp. 24-35, 2006. http://www.jstor.org/stable/29544632

[28] Rousseau, Jean-Jacques, "tale Emile, trans. Allan Bloom. 1762”, New York: Basic Books, 1979.

[29] Laslet, Peter and Philip W. Cummings, "History of Political Philosophy", In The Encyclopedia of Philosophy.Vol.6, Collier-Macmillan Ltd), 1967. p.379.

[30] Quatremère de Quincy, Antoine-Chrysostome, "Allegorie in Encyclopedie Methodique d'Architecture", vol.9, Paris: Panckouke, 1788.

[31] Younes, Samir, "The Imperfect City: On Architectural Judgment ", Routledge, 2012.

[32] Quatremère de Quincy, "Notice historique sur la vie et les ouvrages de. M.Roland', Institut royal de France", La séance publique de l'Académie royale des Beaux-arts, 1819.

[33] Leith, James A., "The Idea of Art as Propaganda in France, 1750-1799", University of Toronto Press, Toronto, 1965.

[34] De Baecque, Antoine, 'The Allegorical Image of France, 1750 - 1800: A Political Crisis of Representation', Representations, No. 47, pp.111, 143, 118. 1994

[35] Quatremère, Etienne. ed. Prolégomènes d'Ebn-Khaldoun, 1332-1406 (Paris: Dupra, 1858).

[36] Ibn Khaldun, "Chapter IV: Countries and Cities and all Other (Forms of) Sedentary Civilization. The Conditions Occurring There. Primary and Secondary (Considerations)," The Muqaddimah of Ibn Khaldun (or Ibn Khaldun's Prolegomena) (1377), translated by Franz Rosenthal (Bollingen Series, XLIII.) 3 vols. (New York: Pantheon. Books):https://asadullahali.files.wordpress.com /2012/10/ibn_khaldun-al_muqaddimah.pdf.

[37] Van Zanten, David, "Architectural Composition at the Ecole des Beaux-arts from Charles Percier to Charles Garnier," In Arthur Drexler ed. The Architecture of the Ecole Des Beaux-Arts, New York: The Museum of Modern Art, 1977, p.135

[38] Quatremère de Quincy, Antoine-Chrysostome, "Extrait du premier rapport présenté au directoire dans le mois de Mai 1791, sur les mesures propres à transformer l'église dite de Sainte-Geneviève en Panthéon Français”, Paris, 1792.

[39] Deming, M. K., "Le Panthéon revolutionnaire", In Le Panthéon: Symbole des revolutions, Catalogue d'exposition, Hôtel de Sully et Montréal, Centre canadien d'architecture, Paris. 1989, pp. 100-5.

[40] Williams, Hannah, "Saint Geneviève's miracles: art and religion in eighteenth-century Paris," in French History, Volume 30, Issue 3, 1 September 2016, pp. 322-353. https://doi.org/10.1093/fh/crv076.

[41] Legrand, J - J., "Déscription de Paris et de ses edifices", Paris, 1808.

[42] Laveaux, Jean-Charles, "Sur les sepultures des grands hommes et celles des autres citoyens," Journal de la Montagne, p. 277, 1793.

[43] Landes, Joan B.," Visualizing the Nation: Gender, Representation, and Revolution in Eighteenth-Century France", Ithaca: Cornell University Press, 2001, p. 136.

[44] Roland, M., "Notice historique sur la vie et les ouvrages de.", Institut royal de France, la séance publique de l'Académie royale des Beaux-arts, 1819, p.8.

[45] Bouwers, E.," Public Pantheons in Revolutionary Europe: Comparing Cultures of Remembrance, c. 1790-1840" Palgrave Macmillan UK; Pantheon, 2011, pp.91-113.

[46] Schneider, Rene, "L'Homme et Sa Vie", In the re-edition of Quatremère De Quincy 1823 De l'Imitation, with an introduction by Leon Krier and Demetri Porphyrios, Brussels; Archives d'architecture Moderne, 1980, pp. XXIX-XLI.

[47] Madrazo, Leandro, "The Concept of Type in Architecture: An Inquiry into the Nature of Architectural Form," Diss. ETH No. 11115, Swiss Federal Institute of Technology, Zürich. 1995.

[48] Haddad, N., "Macedonia, Alexandria, Petra: Tomb Architecture, In International Congress, Alexander the Great: From Macedonia to the Oikoumene", Veria, 27-31. 5. 1998, Greece, 1999, pp. 161-171.

[49] Haddad, N., "Critical Assessment of the Barrel Vault Geometry and Structure of the Oldest Macedonian tomb of Eurydice in Vergina," Mediterranean Archaeology \& Archaeometry, Vol. 15, No.2. pp. 143-162. 2015.

[50] Haddad, N., "The Macedonian Tomb Façade Formation and its Significant Role and Critical Stage for the Development of Hellenistic and Late Classical Façade Morphology", 16th annual international conference on history \& archaeology: from ancient to modern, 2-5July 2018, Athens, Greece, Athens: Athens Institute for education and research (Atiner's conference paper series, no: HIS2018-2561). 